\title{
Pengaruh Komite Audit, Likuiditas, Pergantian Auditor Dan Kompleksitas Operasi Terhadap Ketepatan Waktu Pelaporan Keuangan \\ (Studi Pada Perusahaan Sub Sektor Perdagangan Besar (Grosir) Yang Terdaftar Di Bursa Efek Indonesia (BEI) Tahun 2017-2019)
}

\author{
Widia Mey Krisyanti $^{1 *}$, Gede Adi Yuniarta ${ }^{2}$ iD \\ ${ }^{12}$ Jurusan Ekonomi dan Akuntansi, Universitas Pendidikan Ganesha, Singaraja, Bali \\ *widiamey99@gmail.com1 ${ }^{1 *}$
}

\section{Abstrak}

Penelitian ini memiliki tujuan untuk menganalisis pengaruh variabel komite audit, likuiditas, pergantian auditor dan kompleksitas operasi terhadap ketepatan waktu pelaporan keuangan. Data yang dipakai yakni data sekunder berupa laporan tahunan serta laporan keuangan perusahaan sub sektor perdagangan besar (grosir) yang terdaftar di BEI tahun 2017-2019. Teknik memilih sampel memakai purposive sampling sehingga memperoleh sampel berjumlah 22 perusahaan. Analisis data yang dipakai yakni statistik deskriptif dan analisis regresi logistik dengan program SPSS 25 . Hasil penelitian ini menyatakan bahwa likuiditas berpengaruh positif dan signifikan terhadap ketepatan waktu pelaporan keuangan sedangkan komite audit, pergantian auditor dan kompleksitas operasi tidak berpengaruh terhadap ketepatan waktu pelaporan keuangan.

Kata Kunci : Komite Audit, Likuiditas, Pergantian Auditor, Kompleksitas Operasi, Ketepatan Waktu Pelaporan Keuangan

\section{Abstract}

This study analyses the effect of audit committee variables, liquidity, auditor turnover and operating complexity on the timeliness of financial reporting. The data used are secondary data in the form of annual reports and financial reports of large trading sub-sector companies (wholesale) listed on the Indonesia Stock Exchange in 2017-2019. The technique for selecting the sample used purposive sampling to obtain a sample of 22 companies. The data analysis used is descriptive statistics and logistic regression analysis with the SPSS 25 program. The results of this study state that liquidity has a positive and significant effect on the timeliness of financial reporting, while the audit committee, auditor turnover and operating complexity do not affect the timeliness of financial reporting.

Keywords: Audit Committee, Liquidity, Auditor Turnover, Complexity Of Operations, Timeliness Of Financial Reporting.

\section{Pendahuluan}

Laporan keuangan merupakan salah satu sumber infomasi yang penting dalam bisnis investasi di pasar modal dan disediakan oleh setiap perusahaan yang go public. Sesuai dengan Peraturan Pemerintah dalam Undang-Undang Republik Indonesia Nomor 8 Tahun 1995 tentang Pasar Modal pada Bab X Pelaporan Keterbukaan Informasi dimana perusahaan

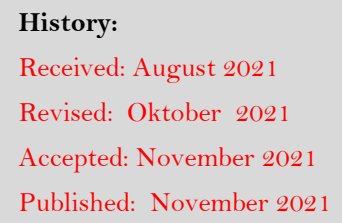


go public wajib melakukan pelaporan keuangan berkala maupun laporan lainnya kepada Badan Pengawas Pasar Modal (BAPEPAM).

Salah satu faktor penting dalam penyampaian laporan keuangan yang menyajikan suatu informasi yang relevan adalah ketepatan waktu (timeliness). Tuntutan akan kepatuhan terhadap ketepatan waktu dalam penyampaian laporan keuangan publik di Indonesia telah diatur dalam Undang-Undang No. 8 Tahun 1995 tentang Pasar Modal. Selain itu, Bapepam mengeluarkan Lampiran Keputusan Ketua Bapepam yang sudah diperbaharui sesuai Peraturan Bapepam Nomor X.K.2, lampiran Keputusan Bapepam Nomor: Kep-36/PM/2003 yang menyatakan bahwa laporan keuangan tahunan harus disertai dengan laporan akuntan dengan pendapat yang lazim dan disampaikan kepada Bapepam selambat-lambatnya pada akhir bulan ketiga (90 hari) setelah tanggal laporan keuangan tahunan.

Berdasarkan data idx pada tahun buku 2017 terdapat 6 perusahaan tercatat yang belum menyampaikan Laporan Keuangan Auditan per 31 Desember 2017. Sedangkan di tahun buku 2018 meningkat terdapat 10 perusahaan tercatat belum menyampaikan Laporan Keuangan Auditan per 31 Desember 2018. Jumlah ini meningkat lagi di tahun buku 2019 terdapat 42 perusahaan tercatat yang belum menyampaikan Laporan Keuangan Auditan per 31 Desember 2019 (idx, 2021). Berikut ini data perusahaan berdasarkan sub sektornya yang terlambat menyampaikan laporan keuangannya pada tahun 2017-2019:

Tabel 1. Data Perbandingan Jumlah Perusahaan Yang Belum Menyampaikan Laporan Keuangan Tahun 2017-2019

\begin{tabular}{|c|c|c|c|c|c|}
\hline \multirow[t]{2}{*}{ No } & \multirow{2}{*}{ Sub Sektor } & \multicolumn{3}{|c|}{ Tahun } & \multirow{2}{*}{ Tota } \\
\hline & & 2017 & 2018 & 2019 & \\
\hline 1. & Minyak dan gas bumi & 2 & 1 & - & 3 \\
\hline 2. & Pertambangan batubara & 1 & 1 & 2 & 4 \\
\hline 3. & Perdagangan besar (grosir) & 2 & 3 & 6 & 11 \\
\hline 4. & Tekstil \& garmen & 1 & - & - & 1 \\
\hline 5. & Makanan \& minuman & - & 1 & 1 & 2 \\
\hline 6. & Property \& real estate & - & 1 & 9 & 10 \\
\hline 7. & Perkebunan & - & 1 & - & 1 \\
\hline 8. & Logam \& mineral lainnya & - & 1 & - & 1 \\
\hline 9. & Otomotif \& komponennya & - & 1 & 1 & 2 \\
\hline 10. & Telekomunikasi & - & - & 1 & 1 \\
\hline 11. & Periklanan & - & - & 1 & 1 \\
\hline 12. & Kimia & - & - & 1 & 1 \\
\hline 13. & Perkebunan & - & - & 1 & 1 \\
\hline 14. & Restoran, hotel dan pariwisata & - & - & 4 & 4 \\
\hline 15. & Pulp \& kertas & - & - & 1 & 1 \\
\hline 16. & Perdagangan eceran & - & - & 5 & 5 \\
\hline 17. & Lembaga pembiayaan & - & - & 1 & 1 \\
\hline 18. & Industri dasar \& kimia lainnya & - & - & 1 & 1 \\
\hline 19. & Minyak \& gas bumi & - & - & 1 & 1 \\
\hline 20. & Transportasi & - & - & 1 & 1 \\
\hline 21. & Farmasi & - & - & 1 & 1 \\
\hline 22. & Mesin dan alat berat & - & - & 2 & 2 \\
\hline 23. & Plastik dan kemasan & - & - & 1 & 1 \\
\hline 24. & Kontruksi dan bangunan & - & - & 1 & 1 \\
\hline & TOTAL & 6 & 10 & 42 & 58 \\
\hline
\end{tabular}


(Sumber: idx.co.id)

Berdasarkan data diatas berarti masih ada perusahaan yang tidak menyampaikan laporan keuangannya secara tepat waktu. Keterlambatan pelaporan keuangan ini dapat mempengaruhi informasi yang dipublikasikan, sehingga akan berpengaruh terhadap ketidakpastian keputusan berdasarkan informasi yang tidak relevan. Berdasarkan data yang terdapat di idx pada tahun buku 2017, BEI mencatat ada 2 perusahaan sub sektor perdagangan besar (grosir) yang terlambat menyampaikan laporan keuangannya antara lain PT Truba Alam Manunggal Engineering Tbk (TRUB) dan PT Evergreen Invesco Tbk (GREN). Sedangkan di tahun buku 2018, BEI mencatat ada 3 perusahaan yaitu PT Sugih Energy Tbk (SUGI), PT Sigmagold Inti Perkasa Tbk (TMPI), dan PT Evergreen Invesco Tbk (GREN). Tahun buku 2019, BEI mencatat ada 6 perusahaan sub sektor perdagangan besar (grosir) yang terlambat antara lain PT Asia Sejahtera Mina Tbk (AGAR), PT Exploitasi Energi Indonesia Tbk (CNKO), PT Evergreen Invesco Tbk (GREN), PT Sugih Energy Tbk (SUGI), PT Tira Austenite Tbk (TIRA) dan PT Triwira Insanlestari Tbk (TRIL) (idx, 2021).

Dengan demikian berarti masih ada setiap tahunnya perusahaan yang terlambat menyampaikan laporan keuangannya. Hal tersebut membuat peneliti mencoba meneliti kembali hal-hal yang berpengaruh terhadap ketepatan waktu pelaporan keuangan khususnya di perusahaan sub sektor perdagangan besar (grosir) yang tercatat di Bursa Efek Indonesia. Peneliti menggunakan beberapa faktor diantaranya yaitu komite audit, likuiditas, pergantian auditor dan kompleksitas operasi.

Teori keagenan memprediksi dan menjelaskan perilaku pihak-pihak yang terlibat dalam perusahaan. Di dalam hukum, agen adalah orang yang dipekerjakan untuk mewakili kepentingan pihak lain. Menurut Jensen and Meckling (1976), hubungan keagenan dapat diartikan sebagai sebuah kontrak antara satu atau beberapa pihak (prinsipal) dengan pihak lain (agen) untuk melakukan beberapa jasa atas nama mereka (prinsipal) dalam mendelegasikan beberapa wewenang pengambilan keputusan kepada agen. Teori agensi memiliki anggapan bahwa setiap individu semata-mata termotivasi oleh kepentingan dirinya sendiri sehingga menimbulkan konflik kepentingan antara prinsipal dan agen.

Teori sinyal merupakan suatu perilaku manajemen perusahaan dalam memberi petunjuk untuk investor terkait pandangan manajemen pada prospek perusahaan untuk masa mendatang (Brigham dan Houston, 2014). Teori sinyal menjelaskan mengenai perusahaan yang berkualitas baik dengan sengaja akan memberikan sinyal kepada publik. Agar sinyal tersebut efektif, maka harus bisa diterima oleh pengguna informasi dengan baik.

Faktor pertama yaitu komite audit. Menurut Hashim dan Rahman (2011) salah satu fungsi penting dalam ketepatan waktu penyampaian laporan keuangan yaitu komite audit. Komite audit dalam fungsi pengawasannya memiliki fungsi penting dalam memengaruhi ketepatan waktu penyampaian laporan keuangan dikarenakan komite audit bertugas untuk mengawasi partisipasi manajemen dan auditor independen dalam proses penyampaian laporan keuangan. Komite audit dapat meningkatkan kualitas proses penyampaian laporan keuangan jika para anggota memiliki independensi, kemampuan dalam memahami laporan keuangan yang baik, tersedianya waktu yang cukup dan melakukan pertemuan secara teratur (Hastuti dan Wahyu, 2017).

Di Indonesia, pedoman pembentukan komite audit menurut Peraturan Otoritas Jasa Keuangan (2015) mewajibkan untuk perusahaan memiliki komie audit yang terdiri dari 3 (tiga) orang. Dengan semakin banyak anggota komite audit yang dimiliki oleh perusahaan, 
maka semakin lebih banyak sumber daya komite audit yang memadai untuk menangani masalah-masalah yang dapat merugikan prinsipal sehingga komite audit dapat mendorong agen (manajemen) untuk menghasilkan laporan keuangan yang tepat waktu. Berdasarkan uraian diatas, maka hipotesis yang disusun dalam penelitian ini sebagai berikut:

$\mathrm{H}_{1}$ : Komite audit berpengaruh negatif terhadap ketepatan waktu pelaporan keuangan.

Faktor kedua yaitu likuiditas. Menurut Fred Weston (dalam Kasmir, 2010) menyebutkan rasio likuiditas merupakan rasio yang menggambarkan kemampuan perusahaan memenuhi utang jangka pendek. Artinya apabila perusahaan ditagih, maka akan mampu untuk memenuhi utang (membayar) tersebut terutama utang yang sudah jatuh tempo. Likuiditas biasa disebut sebagai rasio lancar yaitu pembanding aktiva lancar dibagi utang lancar. Perusahaan yang mampu melunasi utang jangka pendeknya, hal ini adalah kabar baik yang ingin segera disampaikan kepada publik. Maka semakin likuid perusahaan maka semakin tepat waktu dalam penyampaian laporan keuangan. Berdasarkan uraian diatas, maka hipotesis yang disusun dalam penelitian ini sebagai berikut:

$\mathrm{H}_{2}$ : Likuiditas berpengaruh positif terhadap ketepatan waktu pelaporan keuangan.

Faktor ketiga yaitu pergantian auditor. Berakhirnya kontrak kerja yang disepakati antara kantor akuntan publik dengan pemberi tugas akan menyebabkan pergantian auditor dan setelah itu memutuskan untuk memperpanjang dengan penugasan baru. Sesuai dengan Persyaratan Standar Auditing (PSA) No. 16 mewajibkan adanya komunikasi secara lisan maupun tulisan antara auditor sebelumnya dengan auditor pengganti sebelum menerima penugasaan.

Menurut Boynton (2001), terjadinya pergantian auditor dikarenakan beberapa alasan, yaitu: (1) Merger antara perusahaan klien dengan beberapa perusahaan yang awalnya memiliki auditor yang berbeda. (2) Memerlukan adanya jasa profesional yang lebih luas. (3) Merasa tidak puas dengan kantor akuntan publik yang lama. (4) Berkeinginan mengurangi pendapatan audit. (5) Merger yang dilakukan oleh beberapa kantor akuntan publik. Perusahaan yang melakukan pergantian auditor pada periode tersebut akan mengalami proses penyesuaian terhadap auditor baru, hal ini akan mengakibatkan banyak waktu yang digunakan dibandingkan dengan pada waktu perusahaan belum berganti auditor. Berdasarkan uraian diatas, maka hipotesis yang disusun dalam penelitian ini sebagai berikut:

$\mathrm{H}_{3}$ : Pergantian auditor berpengaruh negatif terhadap ketepatan waktu pelaporan keuangan.

Faktor yang keempat yaitu kompleksitas operasi. Menurut Margaretta dan Soepriyanto (2012) tingkat kompleksitas operasi sebuah perusahaan yang tergantung pada jumlah dan lokasi unit operasinya (cabang) serta keberagaman jalur produk dan pasarnya lebih cenderung memengaruhi waktu yang dibutuhkan auditor untuk menyelesaikan pekerjaan auditnya. Hal tersebut dapat memengaruhi ketepatan waktu penyampaian laporan keuangan perusahaan kepada publik. Semakin kompleks kegiatan operasi suatu perusahaan maka perusahaan tersebut semakin lama dalam melaporkan informasi keuangannya. Berdasarkan uraian diatas, maka hipotesis yang disusun dalam penelitian ini sebagai berikut:

$\mathrm{H}_{4}$ : Kompleksitas operasi berpengaruh positif terhadap ketepatan waktu pelaporan keuangan.

Berdasarkan pemaparan tersebut maka penulis ingin melakukan penelitian lebih lanjut mengenai "Pengaruh Komite Audit, Likuiditas, Pergantian Auditor dan Kompleksitas Operasi Terhadap Ketapatan Waktu Pelaporan Keuangan (Studi Pada Perusahaan Sub Sektor 
Perdagangan Besar (Grosir) yang Terdaftar di Bursa Efek Indonesia (BEI) Tahun 20172019).

Berdasarkan pernyataan diatas tujuan penelitian ini yaitu: (1) Untuk menganalisis pengaruh komite audit terhadap ketepatan waktu dalam penyampaian laporan keuangan. (2) Untuk menganalisis pengaruh likuiditas terhadap ketepatan waktu dalam penyampaian laporan keuangan. (3) Untuk menganalisis pengaruh pergantian auditor terhadap ketepatan waktu dalam penyampaian laporan keuangan. (4) Untuk menganalisis pengaruh kompleksitas operasi terhadap ketepatan waktu dalam penyampaian laporan keuangan.

\section{Metode}

Pada penelitian ini menggunakan penelitian kuantitatif dengan teknik pengumpulan data yang digunakan yaitu teknik dokumentasi dengan memakai jenis data sekunder yaitu laporan keuangan dan laporan tahunan. Populasi dalam penelitian ini adalah seluruh perusahaan sub sektor perdagangan besar (grosir) yang sudah go public yang terdaftar di Bursa Efek Indonesia (BEI). Penentuan sampel menggunakan metode purposive sampling.

Adapun kriteria-kriteria yang telah ditentukan dalam pemilihan sampel adalah sebagai berikut: (1) perusahaan yang terdaftar di Bursa Efek Indonesia periode tahun 2017-2019. (2) perusahaan yang mempublikasikan laporan keuangan dan laporan tahunan yang telah diaudit selama periode tahun 2017-2019. (3) perusahaan yang mempunyai kelengkapan data yang diperlukan yang terkait dengan variabel penelitian selama 2017-2019. (4) perusahaan yang mempublikasi laporan keuangan dengan bentuk mata uang rupiah $(\mathrm{Rp})$. Berdasarkan krtiteria yang telah ditetapkan maka jumlah sampel yang digunakan dalam penelitian ini sebanyak 22 x 3 tahun $=66$.

Tabel 2. Proses Seleksi Sampel

\begin{tabular}{|c|c|c|}
\hline No & Keterangan & Sampel \\
\hline 1. & $\begin{array}{l}\text { Perusahaan sub sektor perdagangan besar (grosir) yang terdaftar di BEI } \\
\text { selama periode } 2017-2019 \text {. }\end{array}$ & 40 \\
\hline 2. & $\begin{array}{l}\text { Perusahaan sub sektor perdagangan besar (grosir) yang mempublikasi } \\
\text { laporan keuangan dan laporan tahunan yang sudah diaudit dalam situs } \\
\text { web perusahaan atau BEI selama periode } 2017-2019 \text {. }\end{array}$ & (5) \\
\hline 3. & $\begin{array}{l}\text { Perusahaan sub sektor perdagangan besar (grosir) yang mempunyai } \\
\text { kelengkapan data yang diperlukan yang terkait dengan variabel } \\
\text { penelitian selama periode 2017-2019. }\end{array}$ & (9) \\
\hline \multirow[t]{3}{*}{4.} & $\begin{array}{l}\text { Perusahaan sub sektor perdagangan besar (grosir) yang mempublikasi } \\
\text { laporan keuangan dalam bentuk mata uang rupiah (Rp). }\end{array}$ & (4) \\
\hline & Jumlah perusahaan & 22 \\
\hline & Total sampel $=22 \times 3$ (tahun) & 66 \\
\hline
\end{tabular}

Sumber: Data sekunder, 2021.

Pengukuran variabel komite audit yaitu dengan banyaknya jumlah anggota komite audit yang dimiliki perusahaan (Putri dan Anisma, 2015). Kemudian variabel likuiditas diukur dengan rasio lancar yaitu membandingkan aktiva lancar dengan kewajiban lancar (Bangabua, 2020). Variabel pergantian auditor diukur dengan pengukuran dummy dengan kategori 1 untuk perusahaan yang tidak melakukan pergantian auditor dan kategori 0 untuk perusahaan yang melakukan pergantian auditor (Yunita, 2017). Variabel kompleksitas 
operasi diukur dengan jumlahh anak dan cabang perusahaan yang dimiliki oleh perusahaan (Cristansy dan Aloysia, 2018). Selanjutnya variabel ketepatan waktu diukur dengan variabel dummy dengan kategori 1 untuk perusahaan yang tepat waktu dan kategori 0 untuk perusahaan yang terlambat (Bangabua, 2020).

Metode analisis yang digunakan dalam penelitian ini yaitu uji statistik deskriptif dan uji analisis regresi logistik dengan program SPSS versi 25. Uji analisis regresi logistik terdiri dari (1) uji overall model fit test, (2) uji nagelkerke R square, (3) uji hosmer and lemeshow test, (4) uji ketepatan klasifikasi, (5) uji wald, (6) uji koefisien regresi. Persamaan model regresi logistik yang dipakai dalam penelitian ini dirumuskan seperti berikut ini:

$\mathrm{TL}=\beta 0-\beta 1 \mathrm{ACSIZE}+\beta 2 \mathrm{C}-\beta 3 \mathrm{AUDCH}+\beta 4 \mathrm{COMPLX}+\varepsilon$

Keterangan:

$\begin{array}{ll}\mathrm{TL} & =\text { Ketepatan waktu } \\ \mathrm{B} 0 & =\text { Konstanta } \\ \beta 1, \beta 2, \beta 3, & \beta 4 \quad=\text { Koefisien determinasi } \\ \mathrm{ACSIZE} & =\text { Ukuran komite audit } \\ \mathrm{CR} & =\text { Likuiditas } \\ \text { AUDCH } & =\text { Pergantian auditor } \\ \mathrm{COMPLX} & =\text { Kompleksitas operasi } \\ \varepsilon & =\text { Error }\end{array}$

\section{Hasil dan Pembahasan}

Tabel 3 Hasil Uji Statistik Deskriptif Variabel Data Numerik

\begin{tabular}{cccc}
\hline & $\begin{array}{c}\text { Komite } \\
\text { Audit (X1) }\end{array}$ & $\begin{array}{c}\text { Likuiditas } \\
\text { (X2) }\end{array}$ & $\begin{array}{c}\text { Kompleksitas } \\
\text { Operasi (X4) }\end{array}$ \\
\hline $\mathrm{N}$ & 66 & 66 & 66 \\
Mean & 2.94 & 6.1911 & 8.47 \\
Std Deviation & .387 & 17.83655 & 12.472 \\
Minimum & 1 & .08 & 0 \\
Maximum & 4 & 118.22 & 61 \\
\hline
\end{tabular}

Sumber: Data sekunder yang telah diolah

Pada tabel 2 di atas bisa diketahui jika variabel independen yang terdiri dari komite audit memiliki mean senilai 2,94, standar devisiasi senilai 0,387, minimum senilai 1 dan maksimum senilai 4. Selanjutnya variabel likuiditas memiliki mean senilai 6,1911, standar devisiasi senilai 17,83655, minimum senilai 0,08 dan maksimum senilai 118,22. Variabel kompleksitas operasi memiliki mean senilai 8,47, standar devisiasi senilai 12,472, minimum senilai 0 dan maksimum senilai 61.

Tabel 4. Hasil Uji Statistik Deskriptif Variabel Data Kategorikal

\begin{tabular}{|c|c|c|c|c|}
\hline & & Frequency & Percent & $\begin{array}{c}\text { Cumulative } \\
\text { Percent }\end{array}$ \\
\hline \multirow[t]{2}{*}{ Pergantian Auditor } & Melakukan & 32 & 48.5 & 48.5 \\
\hline & $\begin{array}{l}\text { Pergantian Auditor } \\
\text { Tidak Melakukan } \\
\text { Pergantian Auditor }\end{array}$ & 34 & 51.5 & 100.0 \\
\hline \multirow[t]{2}{*}{ Ketepatan Waktu Pelaporan Keuangan } & Terlambat & 7 & 10.6 & 10.6 \\
\hline & Tepat Waktu & 59 & 89.4 & 100.00 \\
\hline
\end{tabular}


Sumber: Data sekunder yang telah diolah

Pada tabel 3 di atas bisa diketahui jika variabel dependen yakni ketepatan waktu pelaporan keuangan pada perusahaan sub sektor perdagangan besar (grosir) yang terdaftar di BEI periode 2017-2019 terindikasi terlambat menyampaikan laporan keuangan sebesar $10,6 \%$ sedangkan $89,4 \%$ terindikasi menyampaikan laporan keuangannya secara tepat waktu. Variabel independen berupa pergantian auditor melakukan pergantian auditor sebesar 48,5\% sedangkan 51,5\% tidak melakukan pergantian auditor.

Tabel 5. Perbandingan Nilai -2LL Awal dengan -2LL Akhir

Block Number $=0 \quad$ Block Number $=1 \quad \begin{gathered}\text { Penurunan/Ke } \\ \text { naikan }\end{gathered}$

$44.642 \quad 29.019 \quad$ Penurunan

Sumber: Data sekunder yang telah diolah

Pada tabel 4, nilai -2LL awal 44,642 > -2LL akhir 29,019, dapat dikatakan bahwa terjadi penurunan nilai -2LL yang artinya konstanta yang menggunakan empat variabel independen sebagai model dapat dipakai untuk menjelaskan pengaruhnya terhadap pendeteksian ketepatan waktu pelaporan keuangan. Penurunan nilai -2LL menyatakan pada bentuk model yang cocok.

Tabel 6. Model Summary

\begin{tabular}{cccc}
\hline Step & -2 Log Likehood & Cox \& Snell R Square & Nagelkerke R Square \\
\hline 1 & 29.019 & .211 & .429 \\
\hline
\end{tabular}

Sumber: Data sekunder yang telah diolah

Pada tabel 5, Nagelkerke R Square senilai 0,429 dan Cox \& Snell R Square senilai 0,211, yang menyatakan jika variabel independen mempunyai kemampuan untuk menjelaskan variabel dependen ketepatan waktu pelaporan keuangan senilai $0,429(42,9 \%)$ dan faktor lain di luar model sebesar 57,1\%.

Tabel 7. Hosmer and Lemeshow Test

\begin{tabular}{cccc}
\hline Step & Chi-Square & $\mathrm{df}$ & Sig. \\
\hline 1 & 3.229 & 7 & .863 \\
\hline
\end{tabular}

Sumber: Data sekunder yang telah diolah

Pada tabel 6, Chi Square senilai 3,229 dan signifikansi senilai 0,863>0,05 sehingga H0 diterima. Maka bisa dikatakan bahwa analisis selanjutnya dapat dilakukan karena model regresi pada penelitian ini layak untuk dipakai. Hal ini dikarenakan model regresi dengan nilai observasinya tidak mempunyai perbedaan yang signifikan, sehingga bisa dikatakan model regresi cocok dengan data 
Tabel 8 Classification Table

\begin{tabular}{|c|c|c|c|c|c|}
\hline \multicolumn{3}{|c|}{ Observed } & \multicolumn{3}{|c|}{ Prediction } \\
\hline & & & \multicolumn{2}{|c|}{$\begin{array}{c}\text { Ketapatan Waktu Pelaporan } \\
\text { Keuangan }(\mathrm{Y})\end{array}$} & \multirow[t]{2}{*}{$\begin{array}{l}\text { Percentage } \\
\text { Correct }\end{array}$} \\
\hline & & & Terlambat & $\begin{array}{c}\text { Tepat } \\
\text { Waktu }\end{array}$ & \\
\hline \multirow[t]{5}{*}{ Step 1} & Ketepatan & Terlambat & 2 & 5 & 28.6 \\
\hline & Waktu & Tepat & 1 & 58 & 98.3 \\
\hline & Pelaporan & Waktu & & & \\
\hline & Keuangan & & & & \\
\hline & & & & & 90.9 \\
\hline
\end{tabular}

Sumber: Data sekunder yang telah diolah

Pada tabel 4.13, dari 59 sampel penelitian yang di prediksi, 58 sampel diprediksi tepat waktu dalam menyampaikan laporan keuangan atau sebesar 98,3\% dan 1 sampel lainnya gagal diprediksi. Selanjutnya dari 7 sampel yang diprediksi, sebanyak 5 sampel gagal diprediksi atau senilai $28,6 \%$ dan 2 sampel terindikasi melakukan keterlambatan pelaporan keuangan. Nilai overall percentage sebesar $(58+2) / 66=90,9 \%$ yang berarti nilai ketepatan model penelitian yaitu sebesar $90,9 \%$.

Tabel 9 Variables in the Equation

\begin{tabular}{ccccc}
\hline $\begin{array}{c}\text { Step } 1 \\
\text { Variables }\end{array}$ & $\mathrm{B}$ & Wald & Sig. & Exp (B) \\
\hline $\mathrm{X} 1$ & -.856 & 0.14 & .904 & .425 \\
$\mathrm{X} 2$ & 2.169 & 5.388 & .020 & 8.747 \\
$\mathrm{X} 3$ & -.480 & .228 & .633 & .619 \\
$\mathrm{X} 4$ & .120 & 1.687 & .194 & 1.128 \\
Constant & 1.220 & .003 & .954 & 3.388 \\
\hline
\end{tabular}

Sumber: Data sekunder yang telah diolah

\section{Pengaruh Komite Audit Terhadap Ketepatan Waktu Pelaporan Keuangan}

Hipotesis pertama di penelitian ini yaitu komite audit berpengaruh negatif terhadap ketepatan waktu pelaporan keuangan. Hasil uji pada variabel komite audit menunjukkan signifikansi senilai 0,904 >0,05 dan koefisien regresi senilai $-0,856$. Hasil penelitian ini menunjukkan jika secara parsial variabel komite audit berpengaruh negatif tidak signifikan dalam ketepatan waktu pelaporan keuangan dengan demikian $\mathrm{H} 1$ ditolak, yang artinya komite audit tidak berpengaruh dalam ketepatan waktu pelaporan keuangan.

Koefisien regresi variabel komite audit menunjukkan nilai negatif yang dapat diartikan semakin besar komposisi komite audit dalam perusahaan maka jumlah hari yang dibutuhkan untuk menyampaikan laporan keuangan tahunan akan semakin kecil sehingga publikasi laporan keuangan semakin tepat waktu.

Penelitian tersebut menunjukkan bahwa ukuran komite audit bukan faktor penentu efektivitas komite audit. Besarnya komite audit yang dimiliki oleh perusahaan belum mampu menjamin perusahaan dapat menyampaikan laporan keuangannya secara tepat waktu karena jumlah anggota yang banyak tidak mampu menjamin fungsi yang maksimal dari komite audit 
sehingga belum bisa dipastikan bekerja dengan baik dalam memantau aktivitas manajemen salah satunya mengenai tahap menyampaikan laporan keuangan agar sesuai dengan ketentuan waktunnya (Azhari dan Muhammad, 2019).

Pada penelitian ini komite audit tidak berpengaruh dalam ketepatan waktu pelaporan keuangan. Hasil penelitian ini sesuai dengan penelitian dari Putra dan Ramantha (2015), Azhari dan Muhammad (2019), Effendi (2019), serta Bestari dan Made (2020) yang menyatakan bahwa komite audit tidak berpengaruh pada ketepatan waktu pelaporan keuangan.

\section{Pengaruh Likuiditas Terhadap Ketepatan Waktu Pelaporan Keuangan}

Hipotesis kedua pada penelitian ini yaitu likuiditas berpengaruh positif terhadap ketepatan waktu pelaporan keuangan. Hasil uji pada variabel likuiditas menunjukkan signifikansi senilai $0,020<0,05$ dan koefisien regresi senilai 2,169 . Hasil penelitian ini menunjukkan jika secara parsial variabel likuiditas berpengaruh positif dan signifikan dalam ketepatan waktu pelaporan keuangan sehingga $\mathrm{H} 2$ diterima, yang artinya variabel likuiditas berpengaruh positif signifikan dalam ketepatan waktu pelaporan keuangan.

Koefisien regresi variabel likuiditas menunjukkan nilai positif, yang dapat diartikan adanya pengaruh atau hubungan searah antara likuiditas terhadap ketepatan waktu pelaporan keuangan pada perusahaan sub sektor perdagangan besar (grosir) yang terdaftar di BEI, artinya apabila likuiditas semakin tinggi maka keputusan ketepatan waktu pelaporan keuangan pada perusahaan sub sektor perdagangan besar (grosir) yang terdaftar di BEI semakin tepat dalam melaporkan laporan keuangan dan sebaliknya, jika likuiditas rendah maka ketepatan waktu pelaporan keuangan pada perusahaan sub sektor perdagangan besar (grosir) yang terdaftar di BEI tidak tepat waktu dalam melaporkan laporan keuangan. Berdasarkan uraian di atas maka dapat disimpulkan, hipotesis yang menyatakan bahwa likuiditas berpengaruh terhadap ketepatan waktu pelaporan keuangan pada perusahaan sub sektor perdagangan besar (grosir) yang terdaftar di BEI terbukti diterima.

Hal ini sesuai dengan teori sinyal (signalling theory) menjelaskan bahwa perusahaan yang berkualitas baik dengan sengaja akan memberikan sinyal kepada publik. Perusahaan yang memiliki tingkat likuiditas tinggi menunjukkan bahwa perusahaan tersebut memiliki kemampuan yang tinggi dalam melunasi kewajiban jangka pendeknya (Nurmiati, 2016). Sehingga perusahaan dengan kondisi seperti ini akan cenderung tepat waktu dalam menyampaikan laporan keuangannya. Perusahaan yang mampu melunasi utang jangka pendeknnya merupakan kabar baik yang ingin segera disampaikan kepada publik.

Pada penelitian ini likuiditas berpengaruh positif dalam ketepatan waktu pelaporan keuangan. Hasil penelitian ini sesuai penelitian dari Bangabua (2020), Putri dan Bambang (2015) yang menunjukkan bahwa likuiditas berpengaruh positif terhadap ketepatan waktu pelaporan keuangan.

\section{Pengaruh Pergantian Auditor Terhadap Ketepatan Waktu Pelaporan Keuangan}

Hipotesis ketiga pada penelitian ini yaitu pergantian auditor berpengaruh negatif terhadap ketepatan waktu pelaporan keuangan. Hasil uji pada variabel pergantian auditor menunjukkan signifikansi senilai $0,633>0,05$ dan koefisien regresi senilai $-0,480$. Hasil penelitian ini menunjukkan jika secara parsial variabel pergantian auditor berpengaruh negatif dan tidak signifikan dalam ketepatan waktu pelaporan keuangan sehingga $\mathrm{H} 3$ ditolak, 
yang artinya variabel pergantian auditor tidak berpengaruh terhadap ketepatan waktu pelaporan keuangan.

Koefisien regresi variabel pergantian auditor menunjukkan nilai negatif, yang dapat diartikan perusahaan yang melakukan pergantian auditor pada periode tersebut akan mengalami proses penyesuaian terhadap auditor baru, hal ini akan mengakibatkan banyak waktu yang digunakan dibandingkan dengan pada waktu perusahaan belum berganti auditor. Dengan kata lain, saat pergantian auditor mengalami peningkatan maka akan berdampak pada keterlambatan dalam penyampaian laporan keuangan.

Pada penelitian ini pergantian auditor tidak berpengaruh terhadap ketepatan waktu pelaporan keuangan. Sehingga perusahaan yang melakukan dan yang tidak melakukan pergantian auditor tidak mempengaruhi ketepatan waktu pelaporan keuangan (Putri dan Bambang, 2015). Hasil penelitian ini sesuai dengan penelitian dari Putri dan Bambang (2015), Aliffianti, dkk (2017) serta Desyana (2019) yang menyatakan bahwa pergantian auditor tidak berpengaruh terhadap ketepatan waktu pelaporan keuangan.

\section{Pengaruh Kompleksitas Operasi Terhadap Ketepatan Waktu Pelaporan Keuangan}

Hipotesis keempat pada penelitian ini yaitu kompleksitas operasi berpengaruh positif terhadap ketepatan waktu pelaporan keuangan. Hasil uji pada variabel kompleksitas operasi menunjukkan signifikansi senilai 0,194 > 0,05 dan koefisien regresi senilai 0,120. Hasil penelitian ini menunjukkan jika secara parsial variabel kompleksitas operasi berpengaruh positif dan tidak signifikan dalam ketepatan waktu pelaporan keuangan sehingga $\mathrm{H} 4$ ditolak, yang artinya kompleksitas operasi tidak berpengaruh terhadap ketepatan waktu pelaporan keuangan.

Koefisien regresi variabel kompleksitas operasi menunjukkan nilai positif, yang dapat diartikan semakin tinggi tingkat kompleksitas operasi perusahaan maka semakin panjang pula waktu yang dibutuhkan oleh auditor terhadap ketepatan waktu pelaporan keuangan. Hal ini sesuai dengan teori keagenan yang menjelaskan bahwa semakin besar ukuran operasi perusahaan maka semakin banyak informasi yang diungkapkan sehingga meningkatkan biaya agensi, hal tersebut membuat lama proses audit sehingga berdampak pada penyampaian waktu laporan keuangan.

Pada penelitian ini kompleksitas operasi tidak berpengaruh dalam ketepatan waktu pelaporan keuangan. Hasil penelitian ini sesuai dengan penelitian dari Putri dan Bambang (2015), Fajar (2017) dan Nurlen, dkk (2021) yang menyatakan bahwa kompleksitas operasi tidak berpengaruh terhadap ketepatan waktu pelaporan keuangan.

\section{Simpulan dan Saran}

Berdasarkan hasil penelitian serta pembahasan yang telah dibuat maka dapat disimpulkan bahwa 1) Komite audit tidak berpengaruh terhadap ketepatan waktu pelaporan keuangan pada perusahaan sub sektor perdagangan besar (grosir) yang terdaftar di Bursa Efek Indonesia, 2) Likuiditas berpengaruh positif dan signifikan terhadap ketepatan waktu pelaporan keuangan pada perusahaan sub sektor perdagangan besar (grosir) yang terdaftar di Bursa Efek Indonesia, 3) Pergantian auditor tidak berpengaruh terhadap ketepatan waktu pelaporan keuangan pada perusahaan sub sektor perdagangan besar (grosir) yang terdaftar di Bursa Efek Indonesia, 4) Kompleksitas operasi tidak berpengaruh terhadap ketepatan waktu pelaporan keuangan pada perusahaan sub sektor perdagangan besar (grosir) yang terdaftar di Bursa Efek Indonesia. 
Berdasarkan hasil dari penelitian, adapun beberapa saran yang dapat penulis berikan terkait dengan penelitian ini yaitu 1) Bagi manajemen perusahaan sebaiknnya menganalisis ketepatan waktu pelaporan keuangan perusahaan untuk mengantisipasi terjadinya teguran atau sanksi dari OJK apabila tidak bisa melaporkan laporan keuangannya secara tepat waktu sesuai dengan aturan yang telah ditetapkan sebelumnya. Selain itu disarankan untuk tetap meningkatkan kinerjanya agar kondisi perusahaan semakin sesuai dengn tujuan perusahaan dan dapat menyelesaikan laporan keuangannya secara tepat waktu dan 2) Untuk penelitian selanjutnya disarankan untuk memperluas sektor yang digunakan menjadi sampel yang digunakan serta menggunakan periode pengamatan yang lebih panjang sehingga dapat menggambarkan kondisi sesungguhunya. Selain itu dapat menambah variabel-variabel lain yang dianggap bisa mempengaruhi ketapatan waktu pelaporan keuangan seperti profitabilitas, opini auditor atau kepemilikan publik..

\section{Daftar Pustaka}

Allifianti, Widya, dkk. 2017. Pengaruh Profitabilitas, Ukuran Perusahaan dan Pergantian Auditor Terhadap Ketapatan Waktu Dalam Penyampaian Laporan Keuangan (Studi Empiris Pada Sub Sektor Perusahaan Transportasi di BEI 2011-2015). e-Proceeding of Management. Vol. 4 No.2.

Azhari, Fadhli dan Muhammad Nuryatno. 2019. Opini Audit Pemoderasi Pengaruh Profitabilitas, Ukuran Perusahaan, Kepemilikan Institusional dan Komite Audit Terhadap Ketepatwaktuan. Jurnal Ilmiah Akuntansi dan Bisnis (JIAB). Vol. 14 No.1.

Bangabua, Jordi Richardo. 2020. Faktor-Faktor Yang Mempengaruhi Ketepatan Waktu Pelaporan Keuangan Pada Perusahaan Pertambangan Yang Terdaftar di Bursa Efek Indonesia. Skripsi. Fakultas Ekonomi. STIE Indonesia Banjarmasin.

Bestari, Fidia Damba dan Made Dudy Satyawan. 2020. Pengaruh Karakteristik Komite Audit Terhadap Ketepatan Waktu Pelaporan Keuangan (Studi Empiris Perusahaan Perdagangan, Jasa dan Investasi Terdaftar di BEI Tahun 2015-2017). Jurnal Akuntansi Unesa. Vol. 8 No. 2.

Boynton, William C, dkk. 2001. Modern Auditing. 7th Edition. John Willey \& Sons Inc, New York.

Brigham, Eugene F dan Houston, Joel F. 2014. Dasar-Dasar Manajemen Keuangan Buku Satu. Edisi Kesebelas. Salemba Empat: Jakarta.

Cristansy, Jesslyn dan Aloysia Yanti Ardianti. 2018. Pengaruh Kompleksitas Perusahaan, Ukuran Perusahaan dan Ukuran KAP Terhadap Fee Audit Pada Perusahaan MAnufaktur Yang Terdaftar di BEI Tahun 2012-2016. Modus Vol. 20 (2): 198-211.

Desyana, Gita. 2019. Pengaruh Debt to Equity Ratio, Profitabilitas, Kualitas Auditor dan Pergantian Auditor Terhadap Ketapatan Waktu Pelaporan Keuangan Pada Perusahaan Manufaktur Yang Terdaftar di BEI. Jurnal Audit dan Akuntansi. Vol. 8 No.1 Hal. 1-18.

Effendi, Bahtiar. 2019. Komite Audit, Profitabilitas, Solvabilitas dan Ketepatan Waktu Pelaporan Keuangan Perusahaan Manufaktur-Sektor Logam. Business Innovation \& Entreprenuership Journal. Vol. 1 No. 3. 
Fajar, Apri. 2017. “Analisis Faktor-Faktor Yang

Mempengaruhi Ketepatan Waktu Penyampaian Laporan Keuangan Interim (Studi Empiris Pada Perusahaan Manufaktur yang Terdaftar di Bursa Efek Indonesia tahun 2013-2015). Skripsi. Fakultas Ekonomi dan Bisnis. Universitas Lampung: Bandar Lampung.

Hashim dan Rahman. 2011. Audit Report Lag and The Effectiveness of Audit Committee Among Malaysian Listed Companies.

Hastuti, Juwita dan Wahtu Meiranto. 2017. Pengaruh Efektivitas Komite Audit Terhadap Ketepatan Waktu Penyampaian Laporan Keuangan. Diponegoro Journal of Accounting. Vol. 6 No. 1 Hal 1-15.

Jensen and Meckling. 1976. Theory of The Firm: Management Behavior, Agency Cost and Ownership Structure. Journal of Financial Economics. Vol. 3 No.4 pp. 205-360.

Kasmir. 2010. Pengantar Manajemen Keuangan. Kencana: Jakarta.

Margaretta, S dan Soepriyanto. 2012. Penerapan IFRS dan Pengaruhnya Terhadap Keterlambatan Penyampaian Laporan Keuangan. Binus Business Review. Vol. 3, No.2, hal 993-1009.

Nurlen, Fenti dkk. 2021. Pengaruh Konvergensi IFRS, Profitabilitas, Ukuran Perusahaan, Kompleksitas Operasi dan Opini Audit Terhadap Ketapatan Waktu Penyampaian Laporan Keuangan Pada Perusahaan Manufaktur Sub Sektor Makanan dan Minuman di BEI Periode 2014-2018. Parasero Jurnal. Vol. 3 No. 1 Hal. 37-56.

PJOK. 2015. Peraturan Nomor 55 Tentang Pembentukan dan Pedoman Pelaksanaan Kerja Komite Audit. Salinan Peraturan Otoritas Jasa Keuangan Nomor 55/PJOK.04/2015.

Putra, I Gede Ari Pramana Putra dan I Wayan Ramantha. 2015. Pengaruh Profitabilitas, Umur Perusahaan, Kepemilikan Institusional, Komisaris Independen, dan Komite Audit Pada Ketepatwaktuan Publikasi Laporan Keuangan Tahunan. E-jurnal Akuntansi Universitas Udayana. Vol. 10 No. 1.

Putri, Apriliani Issana dan Bambang Suryono. 2015. Berbagai Faktor Yang Mempenagruhi Ketepatan Waktu Pelaporan Keuangan. Jurnal Ilmu \& Riset Akuntansi. Vol. 4 No. 7.

Putri, B.P., Kennedy dan Y. Anisma. 2015. Pengaruh Karakteristik Komite Audit, Fee Audit, Ukuran KAP dan Internal Auditor Terhadap Ketepatan Waktu (Timeliness) Pelaporan Keuangan. Jurnal FEKON. Vol. 2 No.2 Hal 1-15.

Yunita, Trisiana. 2017. “Analisis Faktor-Faktor Yang Mempengaruhi Ketepatan Waktu Penyampaian Laporan Keuangan (Studi Empiris pada Perusahaan Manufaktur yang Terdaftar di BEI Periode 2012-2015)". Skripsi. Fakultas Ekonomi. Universitas Islam Indonesia: Yogyakarta.

www.idx.com 